\title{
Bibliografi over Kaj Thanings forfatterskab
}

\section{8:}

"'Kritisk Revu’.«i: Tidehverv, årg. 2, nr. 10, pp. 141-147

1929:

»Orientering« i: Sursum Corda, årg. 26, nr. 4, p. 9

1930:

»Bolsjevismen - en Religion (1-2)« i: Højskolebladet, årg. 55, nr. 1819 , pp. $537-542+587-592$

1935:

»Fattig og Rig» i: Menighedsbladet, årg. 17, nr. 25, p. $385 \mathrm{ff}$.

"Effata«, i: Menighedsbladet, årg. 17, nr. 36, pp. 561-564

1936:

»Det Barthske og det Grundtvigske« i: Dansk Udsyn, årg. 16, nr. 6, pp. 492-507

»En Præst på sin Post?« i: Prcesteforeningens Blad, årg. 26, nr. 34, p. 630

"'Hans fattige Skikkelse'« i: Menighedsbladet, årg. 18, nr. 48, p. 825f., 1937:

Menighed og Folk«, i: Niels Petersen (ed.), Menighed og Folk, Vallekilde, 1937, pp. 25-34

1938:

»Præstefrihed» i: Menighedsbladet, årg. 20, pp. 785-788

1939:

»Kult eller Kirke.« i: Tidehverv, årg. 13, nr. 9, pp. 103-108

»Forkyndelsen i Dag« i: Dansk Udsyn, årg. 19, nr. 5, pp. 377-385

»Hvor Fr. Schrøder har uret« i: Højskolebladet, årg. 64, nr. 18, p. $281 \mathrm{f}$.

"Ritualer vil forstaas«, i: Højskolebladet, årg. 64, nr. 20, p. 315f.

»Torkild Skat Rørdam« i: Højskolebladet, årg. 64, nr. 31, pp. 490-493 1940:

»Ryslinge-Ritualet« i: Prasteforeningens Blad, årg. 30, nr. 4, p. 79f.

1941:

»Et tredie Grundtvigstandpunkt(1-2)« i: Tidehverv, årg. 15, nr. 8-9, pp. 87-90+99-105

1942:

»En Grundtvigkritik« i: Tidehverv, årg. 16, nr. 2, pp. 19-24

》Omkring Udnævnelsen i Hobro« i: Prcesteforeningens Blad, årg. 32, nr.36, p. $694 f$. 
1943:

»Menighedens Fællesskab eller kristeligt Fællesskab.«i: Tidehverv, årg. 17, nr. 6, pp. 61-67

1944:

»Kirke og Folk« i: Tidehverv, årg. 18, nr. 6, pp. 63-68 »Menighed og Frihed« i: Fyns Venstreblad, 24. november »Et Stykke litterært Detektivarbejde« i: Nationaltidende, (datoangivelse mgl.)

1945:

»Om Clichéer« i: Højskolebladet, årg. 70, nr. 8, p. $79 \mathrm{f}$.

»Bemærkning til Uffe Grosen« i: Højskolebladet, årg. 70, nr. 12, p. 109

\section{6:}

»Svar til Fangel (1-2)« i: Tidehverv, årg. 20, nr. 1-2, pp. 9-12+19-24 »Svar til Pastor H. Skjerk« i: Prcesteforeningens Blad, årg. 36, nr. 48, p. 1049f.

\section{7:}

»Milieu eller Kirke.» i: Højskolebladet, årg. 72, nr. 3-4, p. 32f.+43ff. »Kirkens værste Fjende« i: Højskolebladet, årg. 72, nr. 9, p. $103 \mathrm{ff}$. »Det gode Hjem og Evangeliet« i: Højskolebladet, årg. 72, nr. 28, p. 330 f.

„En Fordel ved Tryksværte» i: Sognet, årg. 1, nr.1, p. 1

»En Bemærkning« i: Sognet, årg. 1, nr. 2, p. 2

„Om nye Salmemelodier« i: Sognet, årg. 1, nr. 2, 4

»Lidt om Standsforskel« i: Sognet, årg. 1, nr. 3, p. 2f.

»Døm ikke!« i: Sognet, årg. 1, nr. 4, p. 1f.

»Vi har svigtet« i: Sognet, årg. 1, nr. 4, p. 4

»I Anledning af Skjerbæks Stykke« i: Sognet, årg. 1, nr. 5, p. 2 f.

»Om Meninger - og hvordan de bliver til« i: Sognet, årg. 1, nr. 6, p. $1 f$.

„Mærkelige Mennesker« i: Sognet, årg. 1, nr. 6, p. 4 ॥Spredte Bemærkninger om Kirkeaaret« i: Sognet, årg. 1, nr. 7-8 1948:

»Brydninger indenfor Folkehøjskolen« i: Højskolebladet, årg. 73, nr. 22, p. 239

»Statshøjskoler« i: Højskolebladet, årg. 73, nr. 39, p. 418

»Født uden for Ægteskabet « i: Sognet, årg. 2, nr. 1, p. 2 »Hvad er en Salme« i: Sognet, årg. 2, nr. 1, p. 3f. »Det, der skiller« i: Sognet, årg. 2, nr. 2, p. 3f. 
»En Søndag som Lægmand" i: Sognet, årg. 2, nr. 4, p. 2 f.

»Paa Færgen« i: Sognet, årg. 2, nr. 5-6, p. 8

»Bør Kirke og Stat skilles« i: Information, 6. marts

1949:

„Grundtvig og den grundlovgivende Rigsforsamling« i: Grundtvig Studier, pp. 35-73

»Nogle Spørgsmaal til Erik B. Nissen« i: Højskolebladet, årg. 74, nr. 6, p. $66 \mathrm{f}$.

»Højskolen 'i det fri' « i: Højskolebladet, årg. 74, nr. 9, p. $102 \mathrm{ff}$.

„Statshøjskoler? (1-3)« i: Højskolebladet, årg.74, nr. 11-13, p. $124 \mathrm{f}$. +133-136+146f.

»Grundtvigs måde at tænke på« i: Prcesteforeningens Blad, årg.39, nr. 30, pp. 479-484

"Jehovas Vidner« i: Sognet, årg. 3, nr. 1, p. 3f.

"Læs, læs, læs« i: Sognet, årg. 3, nr. 2, p. 2

»Af en Begravelsestale« i: Sognet, årg. 3, nr. 3, p. 4

„Om Hyklere og deres Kritikere« i: Sognet, årg. 3, nr. 4, p. 2 f.

"Arbejderen og Foredragsforeningen« i: Sognet, årg. 3, nr. 4, p. 2 f.

1950:

»Er Tidehverv et milieu?(1-2)« i: Menighedsbladet, årg. 32, nr. 22-23, p. $172 \mathrm{ff} .+180-183$

»Dementi.« i: Menighedsbladet, årg. 32, nr. 41, p. 338

»Dementiet fastholdes. « i: Menighedsbladet, årg. 32, nr. 47, p. 389f.

»Er Tidehverv et milieu? « i: Tidehverv, årg. 24, nr. 4, pp. 33-40

»En Kirkeskole?« i: Højskolebladet, årg. 75, nr.10, pp. 103-106

»Tilfredshed eller Glæde« i: Sognet, årg. 4, nr. 1, p. 2 f.

»Grundlovsdag" i: Sognet, årg.4, nr. 2, p. 2

»I anledning af Bartholdy« i: Sognet, årg.4 , nr. 2, p. 4

"De Prædikener« i: Sognet, årg. 4, nr. 3, p. 2f.

»En Digter om Omvendelse« i: Sognet, årg. 4, nr. 3, p. 4

»Lidt om Skyklapper« i: Sognet, årg. 4, nr. 4, p. 2f.

„En politisk lægmand om politik« i: Information, 15. September 1951:

„Synernes Mand - eller Kendsgerningernes! «i: Højskolebladet, årg. 76, nr. 2, pp. 13-16

»Folkekirkeoplysninger« i: Sognet, årg. 5, nr. 1, p. 3

„Svar paa Indvendinger« i: Sognet, årg. 5, nr. 2, p. 2f.

„Paa Lysebu« i: Sognet, årg. 5, nr. 3, p. 2 
1952:

»Kirken - vor Hukommelse« i: Sognet, årg. 6, nr. 1, p. $1 \mathrm{ff}$.

»En Lykønskning« i: Sognet, årg. 6, nr. 2, p. 2 f.

»Kriser« i: Sognet, årg. 6, nr. 2, p. 4

»Gaver« i: Sognet, årg. 6, nr. 3, p. 3

"Spildt Umage« i: Sognet, årg. 6, nr. 3, p. 3f.

»Fra et Naboland" i: Sognet, årg. 6, nr. 4, p. 8

»Indlæg i Grundtvigdiskussion« i: Politiken, 14. juni

»Grundtvig i dag« i: Politiken, 1. september

1953:

»Grundtvigs Møde med Irenæus« i: Grundtvig Studier, pp. 7-68

»Grundtvig og den danske folkehøjskole« i: Dansk Udsyn, årg. 33, nr.6,

p. 331-346

»Amerika - Danmark« i: Sognet, årg. 7, nr. 1, p. $1 \mathrm{ff}$.

»Det hænder - « i: Sognet, årg. 7, nr. 1, p. 4

»Spøg og Alvor« i: Sognet, årg. 7, nr. 2, p. 4

»Traditioner« i: Sognet, årg. 7, nr. 4, p. $5 \mathrm{ff}$.

1954:

»Møde i Lüneburg« i: Sognet, årg. 8, nr. 1, p. 2ff.

»En Juleengel« i: Sognet, årg. 8, nr. 2, p. 3ff.

»Salmerne og deres Melodier« i: Sognet, årg. 8, nr. 2, p. 7f.

1955:

»Det befriede menneske« i: Højskolebladet, årg. 80, nr.14, p. $155 \mathrm{ff}$.

»En amerikansk Grundtvigbog« i: Højskolebladet, årg. 80, nr. 47, p. $538 \mathrm{ff}$.

»En rettelse« i: Højskolebladet, årg. 80, nr. 48, p. 548

»Befrielsen fra hedenskabet« i: Sognet, årg. 9, nr. 1, p. 2f.

»Ugifte mødre« i: Sognet, årg. 9, nr. 2, p. 4

»Dialog over grænserne« i: Information, 31. august

Anmeldelse af 'Danish Rebel' i: Information, 29. december

1956:

„Svar til Johs. Knudsen« i: Højskolebladet, årg. 81, nr. 3, p. 34f.

»Ingeborg Thaning f. Nørregård« i: Højskolebladet, årg. 81, nr. 15, p.

153

»En slags sygdom« i: Sognet, årg. 10, nr. 1, p. 3f.

»En skyldig Gud« i: Sognet, årg. 10, nr. 3, p. 7 f.

1957:

»Og barnet voksede - « i: Højskolebladet, årg. 82, nr. 2, p.16ff.

»Er vi katolikker?« i: Sognet, årg. 11, nr. 1, p. 2 ff. 
»Moral og politik« i: Sognet, årg. 11, nr. 1, p. 4 »Menighedsraadsvalg« i: Sognet, årg. 11, nr. 2, p. 3f

1958:

»Grundtvig 175 år« i: Højskolebladet, årg. 83, nr. 35, p. 409ff.

»Lindhardtsk historieskrivning« i: Højskolebladet, årg. 83, nr. 47, p. $603 \mathrm{ff}$.

»Jacob Christian Lindberg« i: Højskolebladet, årg. 83, nr. 48, p. 620f. »Grundtvig og Kierkegaard» i: Proestéforeningens Blad, årg. 48, nr. 5, pp. 71-74

„Glæde i sorg« i: Sognet, årg. 12, nr. 1, p. 3 f.

»Lidt om højskoler« i: Sognet, årg. 12, nr. 1, p. $6 \mathrm{ff}$.

1959:

»Grundtvig og Lindberg - endnu engang« i: Højskolebladet, årg. 84, nr. 2, p. $29 \mathrm{ff}$.

»Disse Asperupmøder« i: Højskolebladet, årg. 84, nr. 15, p. 239f. »I adventstiden« i: Sognet, årg. 13, nr. 1, p. 7f.

1960:

»Båring Højskole. Indledningen til Båring Højskoles skoleplan« i: Båring Højskole. Arsskrift, p. 3f.

„Martha og Maria. Prædiken ved elev- og efterårsmødet 25. 9. 1960.« i: Båring Højskole. Arsskrift., pp. 29-33

»To modsatte betydninger af de samme ord«i: Sognet, årg. 14, nr. 1, p. 3

„Det, der ellers ikke bliver sagt" i: Sognet, årg. 14, nr. 1, p. 3f.

»Tilføjelse« i: Sognet, årg. 14, nr. 2, p. 4

»Sikkerhed« i: Sognet, årg. 14, nr. 3, p. 2f.

»Frisind« i: Sognet, årg. 14, nr. 3, p. 4

»Han bekriger ideologier og alle idéers tvang« i: Information, 25. juli ॥Svar til Lindhardt « i: Information, 28. juli

1961:

»Kultivering« i: Båring Højskole. Arsskrift. pp. 3-9

»Kultivering« i: Sognet, årg. 15, nr. 1, pp. 3-6

»Efter et fredsvalg« i: Sognet, årg. 15, nr. 1, p. 7f.

"Stagnation eller fornyelse? Grundtvigianismen« i: Berlingske Aftenavis, 5. oktober

1962:

»Om at krænke en livslov« i: Båring Højskole. Arsskrift., pp. 26-30 „Svar paa angreb« i: Dansk Kirketidende, årg. 114, nr. 29, p. 236 
»Gik Grundtvig over til Kolds højskolesyn?«i: Højskolebladet, årg. 87, nr.9, pp. 136-139

»Poul Engbergs højskolepolemik?« i: Højskolebladet, årg. 87, nr. 5, p. 69ff.

"Statusopgørelse« i: Højskolebladet, årg. 87, nr. 13, p. $200 \mathrm{f}$.

$»$ Fortællingens magt« i: Sognet, årg. 16, nr. 2, p. 3f.

1963:

„Gudstjeneste i fjernsynet» i: Dansk Kirketidende, årg. 115, nr. 19, p. $171 \mathrm{f}$.

„Gudstjeneste i fjernsynet" i: Sognet, årg. 17, nr. 1, p. 3f.

Menneske først - Grundtvigs opgør med sig selv, bd 1-3, København: Gyldendal, $794 \mathrm{~s}$.

1964:

„Græske Noter« i: Båring Højskole. Arsskrift., pp. 14-21

»Tre misforståelser« i: Dansk Kirketidende, årg. 116, nr. 35, p. 347f.

»Man first « i: Danish Foreign Office Journal, nr. 48, pp. 29-33

"Grundtvigtolkning« i: Højskolebladet, årg. 89, nr. 19, pp. 305-309

„Forsinket svar til kritiker« i: Højskolebladet, årg. 89, nr. 29, p. 479ff. »Grundtvigs 'nu' « i: Højskolebladet, årg. 89, nr. 35, p. 581ff.

»En bekræftelse« i: Højskolebladet, årg. 89, nr. 38, p. 635

"Svar til en Grundtvigforsker« i: Dansk Udsyn, årg. 44, nr. 6, pp. 447453

»Grundtvigs prædikener (1-2)« i: Praestéforeningens Blad, årg. 54, nr. 5-6, pp. 81-90+101-111

»Afvisning af angreb» i: Proesteforeningens Blad, årg. 54, nr. 22, p. 433-438

»Forventning« i: Sognet, årg. 18, nr. 1, p. 3f.

„Svar til Otto Paludan« i: Kristeligt Dagblad, 4. januar

„Opbyggelsesbog eller videnskab - eller begge dele?« i: Kristeligt Dagblad, 18. februar

"Grundtvigforskeren må nødvendigvis tolke« i: Kristeligt Dagblad, 11. marts

»Fynsk foraar - ved efteraarstide« i: Jyllandsposten, 22. november "X" i: Festskrift udgivet af Københavns Universitet $i$ anledning af universitetets årsfest november 1964.

1965:

„Svar til tre kritikere« i: Grundtvig Studier, pp. 55-89

Grundtvig. Skrifter i udvalg ved Kaj Thaning. Gyldendals bibliotek, bind 6, København, Gyldendal, pp. 349-367. 
»Efterskrift« i: Grundtvig. Skrifter i udvalg ved Kaj Thaning. Gyldendals bibliotek, bind 6, København: Gyldendal, pp. 353-367

1966:

»Nye og gamle Englandsindtryk« i: Båring Højskole. Arsskrift., pp. 1419

»Holdt tesen?« i: Grundtvig Studier, pp. 68-99

"Kirkelig Håndbog« i: Prcesteforeningens Blad, årg. 56, nr. 7, p. 106 »Kirkelig Håndbog - svar til Schjørring og Hauge«, i: Prcestéforeningens Blad, årg. 56, nr. 10, p. 155

„Das Menschliche und das Christliche bei N. F. S. Grundtvig«i: K. E. Løgstrup og E. Harbsmeier (ed.), Kontroverse um Kierkegaard und Grundtvig, Vol. 1, München: Chr. Kaiser Verlag 1966, pp. 50-80 1967:

»Prædiken ved elevmødet 15. Oktober 1967« i: Båring Højskole. Arsskrift., pp. 26-30

„Grundtvig og Tidehverv« i: Tidehverv, årg. 41, nr. 10, pp. 105-116 »Sidelys på Kredsen i tyverne« i: Studenterkredsen, årg. 35, nr. 1-2, pp. 84-92

1968:

॥'Skil stat og kirke'« i: Båring Højskole. Arsskrıft., pp. 10-14; Højskolebladet, årg. 93, nr. 5, pp. 69-71

»Jorden tro« i: Tidehverv, årg. 42, nr. 4-5, p. 54

»Norden og Afrika« i: Fyns Tidende, 13. juni

"Kirke i bånd « i: Information, 18. juni

"'Skil stat og kirke'« i: Aalborg Stiftstidende, 24. december 1969:

»Højskoleskrifterne 1968« i: Højskolebladet, årg. 94, nr. 18, pp. 289293

»Den lille mand og folkekirken« i: Båring Højskole. Arsskrift., pp. 1924

„Grundtvig og den danske folkekirke«i: Dansk Kirkeliv, årg. 46, pp. 3749; Fyens Stiftsbog, pp. 35-45

"Grundtvigs kirkesyn med særligt henblik på den danske folkekirkes forhold til staten(1-2)« i: Dansk Kirketidende, årg. 121, nr. 41-42, pp. 378-382+390-394

»Langfredag 1969« i: Tidehverv, årg. 43, nr. 5, p. 49ff.

"Hvordan er en dialog med fortidens mennesker mulig?» i: Dansk Udsyn, årg. 49, nr. 4, pp. 271-283

»Menighed og storkommune« i: Vejle Amts Folkeblad, 9. juni 
»Den lille mand og kirken« i: Sjollands Tidende, (datoangivelse mangler)

1970:

»Højskoledemokrati« i: Båring Højskole. Arsskrift., pp. 5-11

»Den lille mand og folkekirken« i: Højskolebladet, årg. 95, nr.7, p. $115 \mathrm{ff}$.

»Nogle spørgsmål til Wilhjelm« i: Tidehverv, årg. 44, nr. 4-5, p. $55 \mathrm{f}$. »Die dänische Volkskirche in ökumenischem Zusammenhang» i: K.E. Løgstrup og Ernst Wolf (ed.), Dem Menschen zugute, Beiträge zur evangelischen Theologie, Band 56, pp. 50-63

1971:

For menneskelivets skyld - Grundtvigs opgør med sig selv, København: Gyldendal, $223 \mathrm{~s}$.

»Højskolens grund« i: Højskolebladet, årg. 96, nr. 25, p. 407ff.

»Haarders balancestræben« i: Højskolebladet, årg. 96, nr. 29, p. 484

"Svar til Poul Engberg« i: Kristeligt Dagblad, 10. juli

»I dag intet behov for statshøjskole« $\mathrm{i}$ : Jyllandsposten, 1. august

1972:

»Randnoter til Bultmann (1)« i: Tidehverv, årg. 46, nr. 6, pp. 53-59

》Grundtvigs betydning for Danmark(1-2)« i: Dansk Kirketidende, årg. 124, nr. 36-37, pp. 400-404+412-416

»Grundtvig« i: Vartovbogen, pp. 43-62

Grundtvig le danois,(traduction J.P. Duclos), København: Det Danske Selskab, $179 \mathrm{~s}$.

N.F.S. Grundtvig, (translated by David Hohnen), København: Det Danske Selskab, $180 \mathrm{~s}$.

Der Däne N.F.S. Grundtvig, (Übersetzung Eberhard Harbsmeier), København: Det Danske Selskab, 188 s.

1973:

„Grundtvig, an Introduction« i: Grundtvig Studier, pp. 68-84

»Den unge Knud Hansen« i: Dansk Udsyn, årg. 53, nr. 2-3, pp. 79-98

»Falske alternativer« i: Prcesteforeningens Blad, årg. 63, nr. 18, pp. 277-284

»Den unge Knud Hansen« i: Festskrift til Knud Hansen, særudgave af Dansk Udsyn, 1973, pp. 7-26

"Staten tjener i virkeligheden på folkekirken« i: Aktuelt, 11. april 1974:

»Utopi og realisme« i: Kredsen, årg. 42, nr. 2, pp. 25-28 
»Ejvind Larsen: Grundtvig - og noget om Marx « i: Grundtvig Studier, pp. $86-90$

„Grundtvig og Marx« i: Dansk Udsyn, årg. 54, nr. 3, pp. 186-208 1975:

»Kierkegaard, Grundtvig og Lindhardt« i: Dansk Udsyn, årg. 55, nr. 4, pp. 213-243

»Lindhardts bog om Grundtvig og Kierkegaard $(1-2)$ i: Prcesteforeningens Blad, årg. 65, nr. 39-40, pp. 641-648+657-663

»Dansk Hilsen« i: En Vänbok till Tage Aurell,Ystad: Værmlands Museum, pp. 150-155

1976:

»Randnoter til Bultmann«(2) i: Tidehverv, årg. 50, nr. 6, pp. 63-72 „Bụltmann og humanismen« i: Bent Hahn, Knud Hansen og Sven Holm-Nielsen (ed.), Humanitet og eksistens, København: Gyldendal 1976, pp. 38-57

1977:

»En syditaliensk folkevækkelse« i: Højskolebladet, årg. 102, nr. 13, p. 199

»Gik Grundtvig over til Kolds højskolesyn?« i: Højskolebladet, årg. 102, nr. 34, pp. 540-546

»Grundtvigs opgør med døden, Kierkegaard og sig selv i $1856(1-2) \ll \mathrm{i}$ : Proesteforeningens Blad, årg. 67, nr. 34-35, pp. 553-561+569-577

»Kulturel og kristen identitet« i: Fønix, årg. 2, pp. 240-249

»Italiensk kulturuge« i: Fyns Stiftstidende, 5. maj

1978:

»Med Grundtvig i bagagen« i: Vartovbogen, pp. 93-109

1979:

»For sammenhængens skyld« i: Dansk Kirketidende, årg. 131, nr. 8, pp. 85-92

»Götz Harbsmeier 1910-1979« i: Grundtvig Studier, p. 7ff.

"Enok Mortensen: Schools for Life« i: Grundtvig Studier, p. 66f.

„Grundtvig 'atter aktuel'« i: Højskolebladet, årg. 104, nr. 10, pp. 147150

»Hans Øllgaard« i: Prcesteforeningens Blad, årg. 69, nr. 9, p. $137 \mathrm{f}$. „Hvornår skrev Grundtvig 'O deilige Land'- og hvorfor?» i: Prcesteforeningens Blad, årg. 69, nr. 18, pp. 306-312

1980:

»Grundtvigs gennembrud som forfatter« i: Højskolebladet, årg. 105, nr. 22, pp. 341-345 
N.F.S. Grundtvig, (på koreansk ved Michael W. Chung), København: Det Danske selskab, $259 \mathrm{~s}$.

1981:

»Bultmann endnu engang«(1-2) i: Tidehverv, årg. 55, nr. 2-3, pp. 13$17+29-35$

»Den 'mageløse opdagelse's tilblivelse« i: Grundtvig Studier, pp. 7-29 »Ved Peter Riemanns begravelse« i: Dansk Kirketidende, årg. 133, nr. 15, p. $166 \mathrm{ff}$.

1982:

»Grundtvig - læst af Kaj Thaning(1-3)« i: Højskolebladet, årg. 107, nr. 16, 29+44, pp. 246-249, 453ff.+694ff.

»Prædikenen 31.7. 1825 og dens hidtil utrykte afslutning« i: Grundtvig Studier, p. $17 \mathrm{ff}$.

1983:

Grundtvig,(udg. af Dansk Friskoleforening), København: Gyldendal, »Menneske først og kristen så - « i: Prcestéforeningens blad, årg. 73, nr.37, pp. 601-607

»Grundtvig i dag : i 200-året for hans fødsel kan hans kultursyn stadig eksporteres« i: Aarhus Stiftstidende, 8. september

»Hele verdens Grundtvig« i: Morgenposten, 9. September, (samme artikel, samme dag i: Aalborg Stiftstidende)

1984:

»Ejvind Larsens Grundtvig« i: Dansk Udsyn, årg. 64, nr. 1, pp. 23-41

»Rejsebreve fra USA (1-3)« i: Dansk Kirketidende, årg. 136, nr. 24-26, p. $373 \mathrm{ff} .$, p. $393 \mathrm{ff} .$, pp. $400-403$

"Status på 201-års dagen«, i: Aarhus Stiftstidende, 8. september, (samme artikel, samme dag i: Aalborg Stiftstidende)

1985:

»40 år efter« i: Højskolebladet, årg. 110, nr. 17, p. 251f.

»Hvem var Clara ?« i: Grundtvig Studier, pp. 11-46, 92-96

»Grundtvigs Conception of Christianity« i: Church and Life,(Askov, Minnesota), nr. 2, p. $9 \mathrm{ff}$.

»Grundtvigs View of Culture« i: Church and Life,(Askov, Minnesota), nr. 3, pp. 9-12

1987:

»Fra Grundtvigs sidste hjem« i: Vartovbogen, pp. 97-115

Hokuo no shisoka Guruntovi, (Watanabe Mitsuo yaku), Forlag: Sugiyama Shoten, $272 \mathrm{~s}$. 


\section{8:}

»Uordenskirkelighed« i: Dansk Kirketidende, årg. 140, nr. 23, p. 381 》Gentagne spørgsmål til Helge Grell« i: Dansk Kirketidende, årg. 140, nr. 25 , p. 414

$»$ Kristen først....?« i: Jens Holger Schjørring (ed.), Menneske først, kristen så, Helge Grells Grundtvig-disputats til debat, Århus: Forlaget Anis, 1988, pp. 55-65

»Da Gudsriget blev nutid for Grundtvig«i: Kristeligt dagblad, 30. marts 1989:

»Ikke eet, men tre spørgsmål« i: Dansk Kirketidende», årg. 141, nr. 3, p. 46

1989/90:

»Enkens søn fra Nain« i: Grundtvig Studier, pp. 32-45, 319-323 1990:

»Den 'sækulariserede' Grundtvig« i: Prcesteforeningens Blad, årg. 80, nr. 48 , p. $951 \mathrm{f}$.

1991:

»To årstal : Replik« i: Grundtvig Studier, p. 134ff., 183

»Til Poul Haahr!« i: Prcesteforeningens Blad, årg. 81, nr. 41, p. 806 1992:

»Replik» i: Grundtvig Studier, pp. 93-96

1994:

»Menighed og Folk» i: Vartovbogen, pp. 131-144 